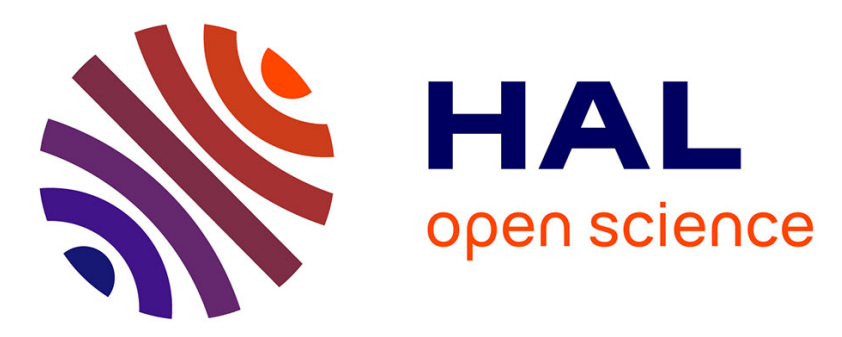

\title{
Influence of retailers' commitment to sustainable development on store image, consumer loyalty and consumer boycotts: Proposal for a model using the theory of planned behavior
}

Laure Lavorata

\section{To cite this version:}

Laure Lavorata. Influence of retailers' commitment to sustainable development on store image, consumer loyalty and consumer boycotts: Proposal for a model using the theory of planned behavior. Journal of Retailing and Consumer Services, 2014, 21 (6), pp.1021 - 1027. 10.1016/j.jretconser.2014.01.003 . halshs-01764748

\author{
HAL Id: halshs-01764748 \\ https://shs.hal.science/halshs-01764748
}

Submitted on 11 Jan 2021

HAL is a multi-disciplinary open access archive for the deposit and dissemination of scientific research documents, whether they are published or not. The documents may come from teaching and research institutions in France or abroad, or from public or private research centers.
L'archive ouverte pluridisciplinaire HAL, est destinée au dépôt et à la diffusion de documents scientifiques de niveau recherche, publiés ou non, émanant des établissements d'enseignement et de recherche français ou étrangers, des laboratoires publics ou privés. 


\section{Influence of retailers' commitment to sustainable development on store image, consumer loyalty and consumer boycotts: Proposal for a model using the theory of planned behavior}

Article in Journal of Retailing and Consumer Services · February 2014

DOI: 10.1016/j.jretconser.2014.01.003

CITATIONS

3

1 author:

\section{Laure Lavorata}

Université de Reims Champagne-Ardenne

16 PUBLICATIONS 26 CITATIONS

SEE PROFILE
READS

81 


\title{
Influence of retailers' commitment to sustainable development on store image, consumer loyalty and consumer boycotts: Proposal for a model using the theory of planned behavior
}

\author{
Laure Lavorata* \\ Université East of Paris, Institute of Management Research, 61 avenue du général de gaulle IUT TC, Université Paris 12, 94000 CRETEIL, France
}

\section{A R T I C L E I N F O}

\section{Article history:}

Received 23 July 2013

Received in revised form

13 December 2013

Accepted 12 January 2014

Available online 5 February 2014

Keywords:

Sustainable development

Retailers

Consumer's loyalty

Image

Boycott

\begin{abstract}
A B S T R A C T
This research has a twofold objective: first, to propose a tool for evaluating retailers' commitment to sustainable development as perceived by consumers (RCSD); second, to test a conceptual framework adapted from the Ajzen and Fishbein (1980) model and to study the impact of RCSD on the retailer's image, consumer loyalty and boycotts. Structural equation modeling was used to test the hypothesized relationships. The study confirms the link between RCSD and the consumers' positive image toward the retailer and suggests that sustainable development practices can help retailers build a good image among consumers. But there is no link between RCSD and consumer loyalty, showing that sustainable development is not a purchase criterion for consumers.
\end{abstract}

(c) 2014 Elsevier Ltd. All rights reserved.

\section{Introduction}

"Retailing with a difference. Retailing with a conscience. Retailing is not about maximizing profits. Nor is it about seeing a fantastic opportunity and saying "hey we can make big bucks there'. That is not retailing" (Suzanne Ackerman Berman/Pick n Pay, Corporate Transformation Director, quoted by Morrison and Humlen, 2013). These words show that retailers have become aware that they need to take sustainable development into account in their practices. Defined by the Brundtland (1987) report as "development that meets the needs of the present without compromising the ability of future generations to meet their own needs", sustainable development has increasingly figured in company policies and is today regarded as an important business goal by many stakeholders (Sheth et al., 2011). Over the last few years, retailers have been implementing various practices that take account of sustainable development: elimination of plastic bags at checkouts, reduction of $\mathrm{CO}_{2}$ emissions, internal codes of good conduct (e.g. in relation to child labor), improvement of employment practices (male/female wage parity, hiring of handicapped workers, etc.), and so forth. In the UK, Tesco has a policy of using wood products from certified sources and Sainsbury's is committed to combating obesity. In the United States, Wal-Mart has since 2005 published an annual report with regard to its environmental commitments (greenhouse gas emissions reduction, etc.)

\footnotetext{
* Tel.: +33 1451719 26/336811942 01; fax: +33145171928.

E-mail address: lavorata@u-pec.fr
}

and has positioned itself as a "green and socially responsible company". This positioning can be understood as a desire to enhance its image, since according to one study, $8 \%$ of Wal-Mart customers have stopped recommending the brand because of its reputation (Damperat and Dussart, 2007). In France, Monoprix has since 1998 been enlarging its provision of "sustainable" products (organic products, environmentally friendly products, and fair trade products) and encourages people to change their consumption patterns by purchasing products for their quality-of-life characteristics, including sustainable development in their design.

Aggeri et al. (2005, p. 15) show that companies' discourses and approaches regarding sustainable development frequently express "a desire to be in compliance with social demands, in the knowledge that such compliance is merely symbolic and has little connection with the company's real business". Thus mass retailing needs to find new models, and to focus on its customers and not only its shareholders: the issue for retailers is on one hand better satisfying consumers by introducing more fair trade products and on the other setting up local initiatives and building real partnerships with its suppliers. Consumers thus expect concrete evidence of retailers' social commitment and, as stakeholders, they can play a major role in the development of retailers' sustainable development practices. It therefore seems relevant to analyze not only consumers' perception of such practices, but also the impact on their behavior. For Sheth et al. (2011), a customer-centric approach to sustainability is of critical interest for all firms endeavoring to prosper in today's environment and intending to continue doing so in the future. As underlined by Hult (2011), market-focused sustainability means greater market orientation. However, 
Chabowski et al. (2011, p. 56) note "that sustainability research has not become a widely studied topic in premier marketing journals" and such studies focus primarily on green marketing (Polonsky, 2011). Yet although there has been considerable research devoted to the retail sector (Journal of Retailing or Journal of Retailing and Consumer Services, for example), there are still relatively few academic studies that focus on sustainable development in the field of retailing and analyze this concept from the consumers' point of view. For example, Oppewal et al. (2006) have attempted to establish a link between socially responsible practices in shopping malls and their attractiveness as perceived by consumers. Other researchers have studied the influence of sustainable development actions on consumers' shopping behavior (Schramm-Klein et al., 2009) or the CSR commitments reported by the UK's 10 leading retailers, including Marks and Spencer and Tesco (Jones et al., 2007). The findings often reveal the influence of such actions on consumer attitude or trust, but few studies have attempted to provide a tool for measuring sustainable development as perceived by consumers, and these studies do not propose models but only investigate links between variables.

This research therefore has a twofold objective. First, we propose a tool for evaluating retailers' commitment to sustainable development as perceived by consumers, that we will call RCSD. Indeed, as pointed out by McWilliams et al. (2006) and Chabowski et al. (2011), research on sustainable development in marketing is in its infancy and theoretical frameworks, measurement, and empirical methods have yet to be established. We hope our research will fill this gap. Second, there is no consensus on a single model, even though Sheth et al. (2011) have developed a consumer-centered model incorporating sustainable development. We therefore decided to use Ajzen and Fishbein's (1980) theory of planned behavior in this study, because when referring to behavior and attitude in marketing, it is the most frequently used (Pookulangara et al., 2011) and seems to be appropriate for studying sustainable development. We propose testing a conceptual framework adapted from this model by integrating the impact of RCSD on retailers' brand and on consumers' loyalty or boycott.

\section{Theoretical framework of the research and hypotheses development}

Aggeri et al. (2005, p. 2) emphasize that sustainable development is associated with positive values and "is an elastic concept that everyone can give a different meaning to". Companies have, moreover, appropriated this definition, and the notion of sustainable development has become "synonymous with durability, or even a management tool" (Capron and Quairel-Lanoizelée, 2004, p. 22). They add that corporate social responsibility (CSR) comes to be the concrete expression of sustainable development issues or the contribution of businesses to sustainable development. But for authors such as Hult (2011), there is a difference between the two concepts because "market-focused sustainability can be a strategic resource" (p. 2): consumers are not included in the CSR framework and consequently are not connected to the organization's competitive advantage. In the retail sector, consumers appear to be the most important stakeholder: in this theory, stakeholders are individuals or groups with legitimate interests in regard to the company (Donaldson and Preston, 1995), and Pasquero (2005, p. 22) points out that "the social positioning of the company and its discourse aims to ensure the company's legitimacy by establishing the relevance of its business in relation to society's needs". But in reality, criteria other than legitimacy play a part, particularly power (Mitchell et al., 1997): in the retail sector, companies must not only legitimate their business in the eyes of consumers, but must also take into account the power of consumers. They put pressure on retailers to define the rules in regard to social practices - trade unions, human rights at work, banning of child labor, good governance and transparency of management, while also demanding products that meet environmental criteria (Capron and Quairel-Lanoizelée, 2004). But the question arises as to the best way of measuring sustainable development.

\subsection{How can retailers' sustainable development be measured?}

In order to differentiate economic performance (oriented toward shareholders' interests) from performance oriented toward all stakeholders, the concept of corporate social performance has been developed (Pasquero, 2005). Thus in the 1990s there emerged the Triple Bottom Line approach under the impetus of financiers who, over and beyond a company's financial performance, wanted to measure its societal performance. This term Triple Bottom Line distinguishes three aspects of sustainable development - economic ("profit"), social ("people") and environmental ("planet") - and, moreover, many companies use it in their sustainable development reports and press releases (e.g. Shell, Dow Chemicals, Carrefour, Auchan, etc.). According to the Triple Bottom Line terminology, a certain number of indicators are provided around the three pillars of sustainable development: economic (products, etc.), social (professional training, malefemale parity, etc.) and environmental (reduction of packaging, reduction of $\mathrm{CO}_{2}$ emissions, etc.). Thus organizations such as the global reporting initiative (GRI) promote this tool, which provides "a sustainable development reporting reference system that is as credible as financial reporting, that is, founded on principles of comparability, rigor and verifiability" (Aggeri et al., 2005, p. 94). For Chabowski et al. (2011, p. 56), these dimensions may be viewed "as the basis for integral market-oriented resources, capabilities and competitive advantage vis-à-vis marketplace competitors". We decided to use these three indicators to measure RCSD because they can help researchers analyze sustainable development practices.

\subsection{Adaptation of the Ajzen and Fishbein model}

In Ajzen and Fishbein's theory, "behavior is a function of a person's intention, which in turn is hypothesized to depend on that person's attitude toward the behavior and his/her subjective norms" (Bagozzi et al., 1992, p. 500). Ajzen and Fishbein (1980) defined behavioral intention as "an individual's likelihood of engaging in the behavior of interest" and it is the direct antecedent of the actual behavior. As indicated by Bagozzi et al. (1992), behavioral intention is a mediating variable between subjective norms (a), perceived behavioral control (b), attitude (c) and behavior Subjective norms are defined as the individual's perception that "most people who are important to him or her believe that he should or should not perform the behavior in question" (Fishbein and Ajzen, 1975, p. 302). In a consumer context, shoppers' purchase decisions are likely to be influenced primarily by family and nonfamily referents (Pookulangara et al., 2011). In the case of sustainable development, it can be supposed that subjective norms have a major effect on behavioral intentions, insofar as consumers believe it to be socially acceptable to buy fair trade products or that they should boycott particular retailers. Moreover, as shown by Oberseder et al. (2011), an important variable in integrating CSR into consumer behavior is peer influence, which can be linked to subjective norms. The second variable (b), perceived behavioral control, is defined as the individual's belief as to the ease or difficulty of adopting a particular behavior (Ajzen and Fishbein, 1980). Usually results show the positive influence of this variable on behavioral intention (Ajzen and Fishbein, 1980; Pookulangara et al., 2011). 
Hypothesis 1. Behavioral control positively influences the consumer's behavioral intention.

Hypothesis 2. Subjective norms influence positively the consumer's behavioral intention.

The third variable (c) attitude is a function of beliefs and the evaluation of those beliefs (Pookulangara et al., 2011). In the case of sustainable development, the perception that consumers have of retailers' commitment to sustainable development can be considered as a set of beliefs and can replace the attitudinal variable. When studying the influence of sustainable development on consumer behavior, researchers find no link: Oppewal et al. (2006, p. 272) showed that "if localness of actions resulted in more positive perceptions of support for the local community, there was no observable direct impact on shopping behavior, suggesting there is no effect on sales". Other authors maintain that when asked, consumers declare their willingness and motivation to consider CSR, but when it comes to real consumption, only very few take account of CSR (Pam et al., 2006; Oberseder et al., 2011). Based on the discussion above, we put forward the following hypotheses:

\section{Hypothesis 3. RCSD influences the consumer's behavioral} intention.

Hypothesis 4. The consumer's behavioral intention influences his/ her behavior.

\subsection{Impact of RCSD on brand image, loyalty and boycott}

CSR is reported to affect, directly or indirectly, the image of brands and can increase consumers' satisfaction (Luo and Bhattacharya, 2006). Other studies have shown its influence on the reputation of the company and consumer loyalty (Stanaland et al., 2011). Taking account of sustainable development can be a means of enhancing the added value of the brand, which can also become a good way of maintaining the credibility of the retailer's public relations. Researchers often focus on CSR: for example, Ellen et al. (2006, p. 148) contend that CSR is a key criterion in gauging corporate reputation and that CSR associations "that reflect the organizational status and activities with respect to its perceived societal obligations" could help them to build trust among consumers. For McWilliams et al. (2006, p. 5), "in contrast to the ease of valuing CSR attributes (taste, quality, etc.), consumers often find it difficult to determine if firm's internal operations meet their moral and political standards for social responsibility". For instance, companies such as McDonalds (US), Wal-Mart (US), Carrefour and Auchan (Fr) publish annual reports on social responsibility, though some consumers perceive this information as biased, since it is filtered through senior management. Wagner et al. (2009) examine the effects of varying configurations of inconsistent CSR information on consumers, and their results show that a proactive communication strategy (when the firm's CSR statements precede conflicting observed behavior) leads to higher levels of perceived hypocrisy than a reactive strategy (when the firm's CSR statements follow observed behavior). Thus, this study suggests our fifth hypothesis:

\section{Hypothesis 5. RCSD influences the retailer's image among} consumers.

When analyzing retailers and consumer motivations, Megicks et al. (2008) found that when consumers make decisions about ethical and socially responsible choices, their motivations will vary according to the situation and will therefore be multi-dimensional in nature. Their findings indicate that "when the consumer's intention is to satisfy urgent needs for a few products on a top- up shop the significance of global ESR issues diminishes, and, whilst local issues still remain relevant, they become less important in store choice" (p. 650). Oberseder et al. (2011, p. 453) noted that consumers agree on the lesser importance of CSR compared to other purchase criteria such as price, quality, brand, country of origin, and service. This finding conforms to previous research, which shows that CSR is not "at the top of many consumers' lists". They show that there are three additional factors before taking a company's CSR initiatives into account for consumers' purchasing decisions: the image of the company, the credibility of CSR initiatives, and the influence of peer groups. This is consistent with Diallo's (2012) study, which showed that the direct and positive relationship between store image and purchase intention was not significant. This author also insisted that "retail managers must be then aware that improving store image does not always lead directly to greater purchase intention" (p. 365).

Hypothesis 6. RCSD does not influence consumers' loyalty.

Bray et al. (2011) identify exogenous (consumer characteristics) and impeding variables in ethical consumption and their impact on various consumer behavior outcomes and they highlight the importance of boycotts: some consumers avoid particular products and brands when they have reason to question the companies' ethical credibility. In our research, it seems thus pertinent to focus on consumers' boycotts because they can be devastating for sales and the company's brand image (Braunsberger and Buckler, 2011). A boycott occurs "when a number of people abstain from purchase of a product, at the same time, as a result of the same egregious act or behavior, but not necessarily for the same reasons" (John and Klein, 2003, p. 1198). Thus, consumers participate in boycotts to express extreme dissatisfaction with a company's actions and/or policies (Braunsberger and Buckler, 2011). We decided to adapt hypotheses 3 and 4 and to focus only on consumers' boycott:

Hypothesis 3 (adapted). RCSD influences the consumer's boycott intention.

Hypothesis 4 (adapted). The consumer's boycott intention influences his/her behavior (boycott).

Among individual factors that can influence RCSD, we decided to study the impact of ethical consumption: as noted by Bray et al. (2011), many participants in their study were influenced in regard to purchase decisions by ethical considerations and avoided products or brands that they considered to have poor ethical standards.

\section{Hypothesis 7. Ethical consumption influences RCSD.}

We decided to test the model as follows (Fig. 1).

\section{Research methodology}

In order to develop a scale in order to measure RCSD, we carried out a qualitative study, then a quantitative study, among consumers. We tested the research model with AMOS 20.00 software.

\subsection{Scale development}

We interviewed 15 French consumers: eight female and seven male, aged from 25 to 65 . For reasons of geographical access, the majority of the respondents came from the Paris region. The aims of this qualitative study were twofold: (1) to identify the links between sustainable development and mass retailing as perceived by consumers; (2) to determine the consequences in terms of behavior (loyalty, shopping habits, boycotts, etc.) as expressed by the consumers. All interviews were transcribed and subjected to a 
thematic content analysis. Miles and Huberman (1984) emphasize also the importance of specific techniques that enable the qualitative data to be analyzed. Our categories were constructed $a$ posteriori according to the words used by the respondents, but following the different stages of the interview guide. A thematic analysis was then carried out, after coding the various themes and sub-themes. This analysis was subject to double coding by two researchers. We classified their answers according to the three categories suggested by Bottom Line: economic, environmental, and social. We then constructed items for each category, finally obtaining 22 items for measuring retailers' commitment to sustainable development as perceived by consumers: these items were constructed as assertions by consumers about retailers' sustainable development. For example, "Hypermarkets engage in actions directed at schools".

We conducted a quantitative study on 252 French consumers in March 2011, using the quota method to ensure homogeneity in terms of age, gender ( $50 \%$ female and male) and socio-professional standing. A demographic profile of the respondents (summarized in Appendix A), indicated that $56 \%$ were under 40 years old and $44 \%$ were 40 or over, and they all came from the Paris region. Participants included students (20\%), functionaries (15\%) and middle or upper management (31\%). These respondents were interviewed at home and not in hypermarkets in so as to obtain a larger sample, and not only customers of a particular hypermarket. They frequent three major hypermarkets (Carrefour $42.5 \%$, Auchan 17.5\%, and Leclerc 15.9\%), while other hypermarkets account for less than $6 \%$.

In the first stage, we carried out a factor analysis using SPSS 12.00 software to verify the criteria of validity and reliability for the measurement scales. We chose to proceed first to a refinement stage and thus to eliminate items whose goodness-of-fit was less than 0.5 , then to proceed by stages in order to obtain satisfactory indices. We finally retained 12 items and 3 dimensions for the RSCD scale, which explained $50.5 \%$ of the phenomenon, thus providing a satisfactory fit (see Appendix B). KMO of 0.790 and Cronbach's alpha of 0.748 were both satisfactory. For the model's other variables, we carried out a factor analysis to verify the criteria of validity and reliability for the measurement scales used: when these were moderate, we eliminated items that were not satisfactory; all of them revealed one factor (Table 1).
Some variables are measured by a single item: behavioral intention ("If your hypermarket has non-responsible practices, would you decide not to go anymore?"), behavior ("Have you boycotted your hypermarket?"), loyalty ("Do you always go to the same hypermarket?") and ethical consumption ("Do you buy organic products"). Although single-item scales are generally little used in marketing, Bergkvist and Rossiter (2008) have demonstrated their effectiveness. Accordingly we considered it unnecessary to add new items.

\subsection{Structural model and hypothesis testing}

We next tested the research model with AMOS 20.00 software. The model's fit indices are satisfactory, in that the value of RMSEA is less than 0.08 (0.062 in this study). GFI is higher than 0.9 (0.906), but the AGFI index is below this limit $(A G F I=0.877)$. The incremental indices (IFI and TLI), which measure the improvement of fit by comparing the model tested to a standard model (Roussell et al., 2002), must be higher than 0.9. In our case, one is acceptable $(I F I=0.906)$, but the other is below the threshold $(T L I=0.889)$. However, as Bollen (1989) points out, "knowledge of the factors influencing the value of an index and common sense are the best guides for evaluating the results obtained". Similarly, Roussell et al. (2002) show that these limit values are primarily an indication of standards and not an indisputable threshold for rejecting the model. For this reason, we decided to keep all these items so as to conserve the model's consistency, without trying at all costs to improve the indices through the elimination of one or more items. To validate our hypotheses, we verify them with Student's $t$-test, which must be higher than 1.96 (Table 2).

\section{Results and discussion}

The study yields a number of findings. We can notice the positive impact of perceived control on behavioral intention $\left(\mathrm{H}_{1}\right)$, which means that consumers think they can act and decide to boycott the retailer. Despite not having participated in a boycott, they nevertheless think that it is in their power to influence the retailer. This finding should encourage retailers to be more vigilant regarding their sustainable development actions and to take into account the fact that although consumers' civic awareness does

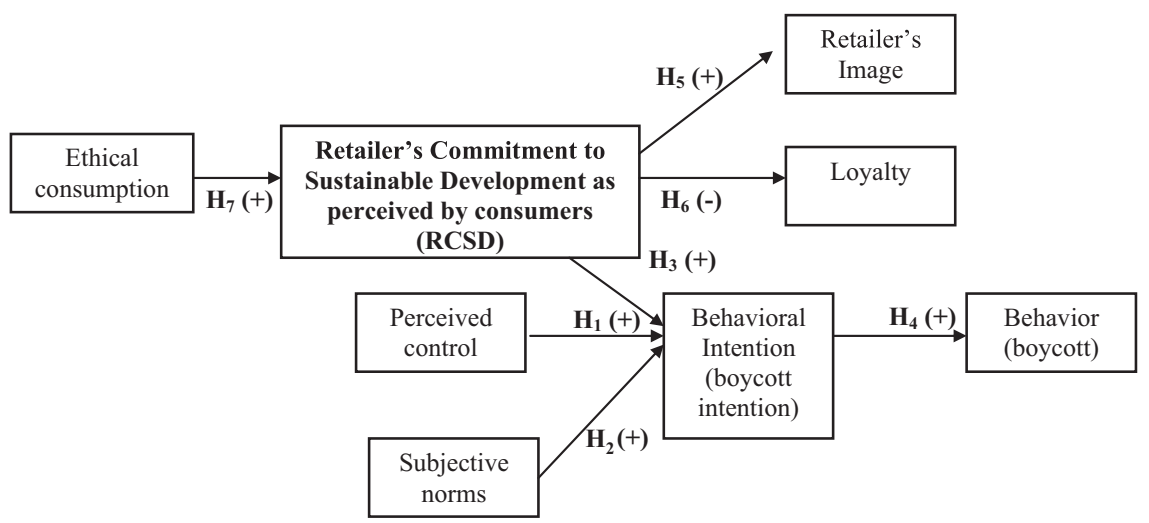

Fig. 1. Research model.

Table 1

Factor analysis.

\begin{tabular}{|c|c|c|c|c|}
\hline Variable measured & Final number of items & Percentage of variance (\%) & Cronbach's alpha & Goodness-of-fit \\
\hline Perceived control & 2 & 70.4 & 0.579 & G1 0.839, G3 0.839 \\
\hline Subjective norms & 3 & 79 & 0.866 & F1 0.935, F2 0.891, F3 0.839 \\
\hline Retailer's image & 4 & 62 & 0.840 & I5 0.670, I6 0.848, I7 0.859, I8 0.788, I9 0.759 \\
\hline
\end{tabular}


Table 2

Research hypotheses.

\begin{tabular}{|c|c|c|}
\hline Hypothesis & $t$ value & Results \\
\hline Hypothesis 1 . Behavioral control positively influences the consumer's behavioral intention & 4.327 & Confirmed \\
\hline Hypothesis 2 . Subjective norms influence positively the consumer's behavioral intention & 4.975 & Confirmed \\
\hline Hypothesis 3. RCSD influences the consumer's boycott intention & 0.151 & Not confirmed \\
\hline Hypothesis 4 . The consumer's boycott intention influences the his/her behavior (boycott) & -4.456 & Confirmed \\
\hline Hypothesis 5. RCSD influences the retailer's image among consumers & 3.983 & Confirmed \\
\hline Hypothesis 6 . RCSD does not influence the consumer's loyalty & 1.507 & Confirmed \\
\hline Hypothesis 7. Ethical consumption influences RCSD & 2.087 & Confirmed \\
\hline
\end{tabular}

not always manifest itself in their actions, consumers might at some point decide to put pressure on them. Specific actions such as boycotts also reflect this shift among consumers: in the United States, for example, consumers shop in large numbers in a store that decided to use a proportion of its takings on a given day to a sustainable development cause (also known as Carrotmob).

Another result of our study shows the importance of subjective norms on behavioral intention $\left(\mathrm{H}_{2}\right)$ : although the consumer intends boycotting a retailer, this variable may lead him not to do so, in view of pressure by friends or acquaintances (subjective norms). The implication for retailers is that the consumer is not only someone who purchases but is also influenced by other people to buy, or not buy, a product (for example, by other stakeholders, such as NGOs). By integrating sustainable development into their practices, retailers can positively influence all stakeholders and thus help influence their consumers.

The third hypothesis is not confirmed: RCSD does not influence consumers' behavioral intention, a finding that is at odd with Ajzen and Fishbein's results. Thus even if the image consumers have on the retailer is negative, they will not decide to boycott the company. Nevertheless, behavioral intention is an indicator of the consumer's behavior $\left(\mathrm{H}_{4}\right)$, thus confirming Azjen and Fishbein's findings. But the relationship is negative between the two variables: boycotting by consumers is inversely proportional to behavioral intention. This finding shows that if consumers intend to act, they have not in fact boycotted retailers, and it expresses the difficulty for consumers to really act. This confirms Braunsberger and Buckler's (2011, p. 96) results, which showed that "boycott motivations include the belief that consumers have the power to impact the boycott target's bottom line and/or behavior as well as the belief that the boycott will succeed in forcing the target to cease its egregious behavior". Other researchers have found that "consumers consider costs of boycott participation, both in terms of intrinsic product preferences and substitutability, and are less likely to boycott if perceived costs are high" (Sen et al., 2001, p. 411). Although this result may reassure retailers that incorporating sustainable development in their practices has no real impact on consumer behavior, it can be risky in the long term for retailers not to introduce such practices.

Another finding is the consequences of RCSD on consumer's behavior. First, the study shows the positive influence of RCSD on the retailer's image among consumers $\left(\mathrm{H}_{5}\right)$. This result confirms Brunk's (2010, p. 275) study on reputation building and the impact on consumers: "While it is generally assumed that consumers' ethical perceptions are either built on first-hand experiences or other concrete information", that reputation can be influenced "by processes outside the company's direct control". In the absence of concrete information or personal experience, consumers may infer "ethical beliefs". This result is important for retailers because it suggests that sustainable development practices can help them to build commitment and a good image among consumers. But there is no link between RCSD and loyalty $\left(\mathrm{H}_{6}\right)$. We can explain this by the fact that the sustainable development criterion is not the first choice for consumers: for example, in our study, the main reasons for always going to the same hypermarket were proximity (52\%), choice (20\%), price (18.3\%), quality (7\%) and service (2.5\%). This is consistent with previous studies showing that the characteristics of price and of accessibility were very important in store choice behavior (Ou et al., 2006; Megicks et al., 2008). It also confirms the findings of Oberserder et al. (2011), who shows that the evaluation of CSR initiatives is a complex process during which consumers distinguish between core, central and peripheral factors: if consumers do not have any information on or care about CSR initiatives, they do not consider it to be a purchase criterion. Other researchers have shown that improving the store image does not always lead directly to greater purchase intention (Diallo, 2012) and that loyalty is not impacted by the retailer's reputation (Ou et al., 2006).

Among individual variables that can influence RCSD, we tested different variables (gender, age, education), but none of them had an impact on it. The only individual variable that had an influence was ethical consumption and the fact that consumers buy organic products. The last hypothesis $\left(\mathrm{H}_{7}\right)$ was thus verified, which shows the importance of this variable in RCSD: the more consumers know about SD, the more they are conscious of retailers' SD practices and policies and they are able to evaluate it precisely, thus confirming previous research (Megicks et al., 2008).

\section{Conclusion and limitations}

Our main contribution is to propose a tool for measuring retailers' commitment to sustainable development as perceived by consumers. It will enable retailers to determine what actions they should take to incorporate sustainable development into their practices. Until now, researchers have not measured sustainable development practices, and this study confirms the existence of three dimensions (economic, social and environmental) in sustainable development.

But the study has certain limitations. First, the sample was restricted to a small area (the Paris region) and these findings may not be generalizable to countries other than France: it might be interesting to test it in an Anglo-Saxon country in order to verify external validity. Second, though the model's indicators are satisfactory, we can think that further items could be included in the measurement tool, and the scale could be tested again. Another limitation is that RCSD does not influence behavioral intention to boycott. It seems surprising that even if retailers are perceived by consumer as having poor sustainable practices, this has no influence on their intent. But often there is a difference between intent and behavior, and consumers overestimate behavioral intention. We can think that boycotts are a political weapon used by some consumers, but and not by all. It might be more interesting for future research to focus on other variables as purchase intent, store choice, etc. These limitations all represent possible avenues for future research. 
Appendix A. Quantitative study sample

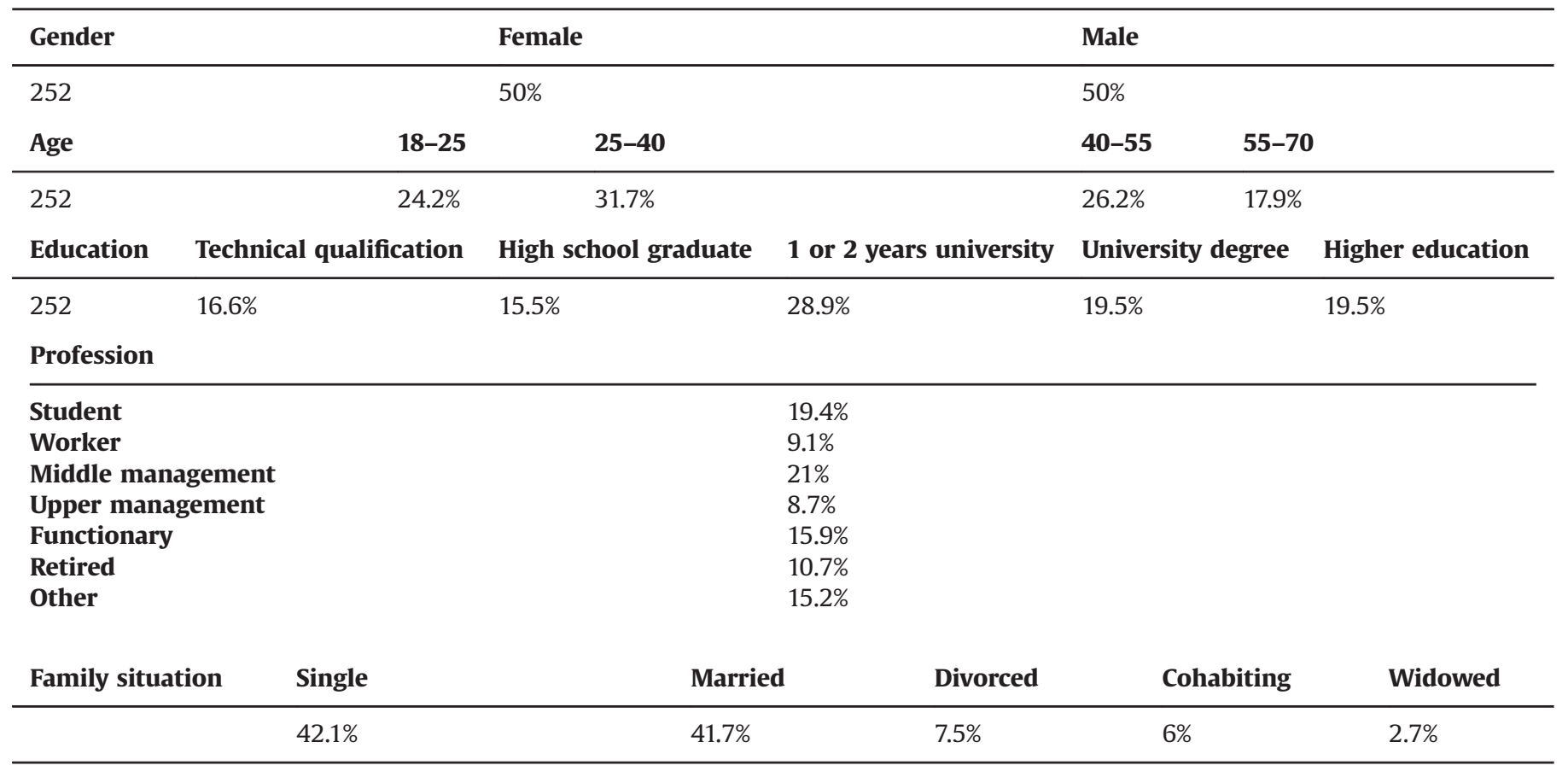

\section{Appendix B. RCSD's scale}

\begin{tabular}{ll}
\hline Factors items & $\mathbf{1}$ \\
\hline A2. Hypermarkets pay producers a fair price & 0.699 \\
A9. Hypermarkets pay their employees a decent wage & 0.740 \\
A27. Hypermarkets pay their employees a minimum wage in developing countries & 0.538 \\
A28. Hypermarkets monitor the working conditions of their employees & 0.651 \\
A1. Hypermarkets sell fair trade products & 0.535 \\
A4. Hypermarkets sell organic products & 0.570 \\
A13. Hypermarkets implement humanitarian actions & 0.661 \\
A14. Hypermarkets engage in actions directed at schools & 0.643 \\
A15. Hypermarkets sell share products (donations to charitable associations) & 0.639 \\
A19. Hypermarkets recycle their products and packaging & 0.711 \\
A20. Hypermarkets cut back their consumer of electricity & 0.778 \\
A21. Hypermarkets pay attention to the environment & \\
Percentage of variance explained & $50.5 \%$ \\
Cronbach's alpha & 0.748 \\
KMO & 0.790 \\
\hline
\end{tabular}

\section{References}

Aggeri, F., Pézet, E., Abrassart, C., Acquier, A., 2005. Organiser le développement durable. Vuibert, Paris.

Ajzen, I, Fishbein, M., 1980. Understanding Attitudes and Predicting Social Behavior. Prentice-Hall, New Jersey.

Bagozzi, R., Baumgartner, H., Yi, Y., 1992. State versus action orientation and the theory of the reasoned action: an application to coupon usage. J. Consumer Res. 18, 505-518.

Bergkvist, L., Rossiter, J.R., 2008. Comparaison des validités prédictives des mesures d'un même construit des échelles mono-tem et des échelles multi-items. Recherche Appl. Market. 23 (1), 81-96.

Bollen, K.A., 1989. Structural Equations with Latent Variables. Wiley and Sons, New York.

Braunsberger, K., Buckler, B., 2011. What motivates consumers to participate in boycotts: lessons from the ongoing Canadian seafood boycott. J. Bus. Res. 64, 96-102.
Bray, J., Johns, N., Kilburn, D, 2011. An exploratory study into the factors impeding ethical consumption. J. Bus. Ethics 98, 597-608.

Brundtland, G.H., 1987. Report of the World Commission on Environment and Development, Our Common Future. United Nations, Oslo, March.

Brunk, K., 2010. Reputation building: beyond our control? Inferences in consumers' ethical perception formation. J. Consumer Behav. 9 (4), 275-292.

Capron, M., Quairel-Lanoizelée, F., 2004. Mythes et réalités de l'entreprise responsable. In: Paris (Ed.), La découverte.

Chabowski, B.R., Mena, J.A., Gonzalez-Padron, T.L., 2011. The structure of sustainability research in marketing, 1958-2008: a basis for future research opportunities. J. Acad. Mark. Sci. 39 (1), 55-70.

Damperat, M., Dussart, C., 2007. Un marketing bien trop vert. Décis. Mark. 47, 101-106

Diallo, M.F., 2012. Effects of store image and store brand price-image on store brand purchase intention: application to an emerging market. J. Retail. Consumer Serv. 19, 360-367.

Donaldson, T., Preston, L., 1995. The stakeholder theory of the corporation: concepts, evidence, and implications. Acad. Manage. Rev. 20 (1), 63-91. 
Ellen, P.S, Webb, D., Mohr, L.M., 2006. Building corporate associations: consumer attributions for corporate socially responsible programs. J. Acad. Mark. Sci. 34 (2), 147-157.

Fishbein, M., Ajzen, I., 1975. Belief, attitude, intention, and behavior: an introduction to theory and research. Addison-Wesley, Massachusetts.

Hult, G.T.M., 2011. Market-focused sustainability: market orientation plus!. J. Acad. Mark. Sci. 39 (1), 1-6.

John, A., Klein, J.G., 2003. The boycott puzzle: consumer motivations for purchase sacrifice. Manage. Sci. 49 (9), 1196-1209.

Jones, P., Wynn, M., Comfort, D., Hillier, D., 2007. Corporate social responsibility and UK retailers. Issues Soc. Environ. Account. 1 (2), 243-257.

Luo, X., Bhattacharya, C.B., 2006. Corporate social responsibility, customer satisfaction, and market value. J. Mark. 70, 1-18.

McWilliams, A., Siegel, D.S., Wright, P.M., 2006. Corporate social responsibility: strategic implications. J. Manage. Stud. 43, 1-18.

Megicks, P. Memery, I. Williams, I. 2008. Influences on ethical and socially responsible shopping: evidence from the UK grocery sector. J. Mark. Manage. 24 (5-6), 637-659.

Miles, M., Huberman, A.M., 1984. Qualitative Data Analysis. Sage Publications, Beverly Hills, CA

Mitchell, R.K., Agle, B.R., Wood, D.J., 1997. Toward a theory of stakeholder identification and salience: defining the principle of who and what really counts. Acad. Manage. Rev. 22, 853-886.

Morrison, G., Humlen, A., 2013. Retailing with purpose: how the pursuit of social responsibility can inspire and sustain retail growth and innovation. J. Brand Strategy 2 (2), 155-169.

Oberseder, M., Schlegelmilch, B.B., Gruber, V., 2011. Why don't consumers care about CSR?': a qualitative study exploring the role of CSR in consumption decisions. J. Bus. Ethics 104, 449-460.
Oppewal, H., Alexander, A., Sullivan, P., 2006. Consumer perceptions of corporate social responsibility in town shopping centres and their influence on shopping evaluations. J. Retail. Consumer Serv. 13, 261-274.

Ou, W.M., Abratt, R., Paul Dion, P., 2006. The influence of retailer reputation on store patronage. J. Retail. Consumer Serv. 13, 221-230.

Pam, E, Webb, D-J, Mohr, L-A., 2006. Building corporate associations: consumer attributions for corporate socially responsible programs. I. Acad. Market. Sci. 34 (2), 147-157.

Pasquero, J., 2005. Responsabilité sociale et environnementale de l'entreprise.. PUQ Quebec (Turcotte, M.F., Salmon, A. (dir.)

Polonsky, M.J., 2011. Transformative green marketing: impediments and opportunities. J. Bus. Res. 64, 1311-1313.

Pookulangara, S., Hawley, J, Xiao, Ge., 2011. Explaining consumers' channelswitching behavior using the theory of planned behavior. J. Retail. Consumer Serv. 18, 311-321.

Roussell, P. Durieu, F. Campoy, E., El Akremi, A., 2002. Méthodes d'équations structurelles: recherche et applications en gestion. Economica, Paris.

Schramm-Klein, H., Zentes, J., Morschett, D., Swoboda, B., 2009. Does corporate social responsibility pay for retailers? In: Proceedings of American Marketing Association (AMA) Winter Educator's Conference, Tampa, FL

Sen, S., Gürhan-Canli, Z., Morwitz, V., 2001. Withholding consumption: a social dilemma perspective on consumer boycotts. J. Consumer Res. 28 (3), 399-417.

Sheth, J.N., Sethia, N.K., Srinivas, S., 2011. Mindful consumption: a customer-centric approach to sustainability. J. Acad. Mark. Sci. 39, 21-39.

Stanaland, A-J-S., Lwin, M-O., Murphy, M-E., 2011. Consumer perceptions of the antecedents and consequences of corporate social responsibility. J. Bus. Ethics 102, 47-55.

Wagner, T., Lutz, R-J., Weitz, B-A., 2009. Corporate hypocrisy: overcoming the threat of inconsistent corporate social responsibility perceptions. J. Mark. 73, 77-91. 